УДК 81.23:37.015.311-028.46

DOI: 10.37026/2520-6427-2019-99-3-108-111
Наталія ШУЛьжУк,

кандидатка філологічних наук, дочентка, завідувачка кафедри стилістики та культури украӥнської мови

Рівненського державного гуманітарного університету

\title{
ПРОБЛЕМА ФОРМУВАННЯ МОВНОЇ ОСОБИСТОСТІ ШКОЛЯРА: КОМУНІКАТИВНО-ПРАГМАТИЧНИЙ АСПЕКТ
}

У статті відзначено, щчо тендениії комплексного підходу до вивчення мовних явиш на трунті нових мовознавчих дисциплін детермінують навчально-педагогічний дискурс, зумовлюючи необхідність комунікативно-прагматичної переорієнтаиії методики навчання мови та внесення коректив до змістового наповнення шкільних підручників з украӥнської мови, зорієнтованих переважно на лінгвочентричну репрезентацію мовних одинииь.

Ключові слова: комунікативна стратегія, комунікативна тактика, інтенція, комунікативна методика, когнітивна методика, кониепт, комунікативно-прагматичні уміння й навички.

В статье отмечено, что тенденции комплексного похода кизучению языковых явлений на почве новых языковедческих дисчиплин детерминируют учебно-педагогический дискурс, вызывая необходимость коммуникативно-прагматической переориентации методики обучения языка и внесения корректив в содержание школьных учебников по украинскому языку, ориентированных преимущественно на лингвоиентрическую презентацию языковых единии.

Ключевые слова: коммуникативная стратегия, коммуникативная тактика, интениия, коммуникативная методика, когнитивная методика, концеепт, коммуникативно-прагматические умения и навыки.

The cognitive-discursive scientific paradigm focused on the study of language as an instrument of communication and influence, that determines the vectors of the development of modern linguistics and linguodidactics, the object of studying of which is the process of acquiring and processing information that is directly related to the implementation of cognitive activity of a person. This, of course, causes shifting emphasis in the language teaching process. The tendencies of a comprehensive approach to the study of language phenomena on the basis of psychology, sociology, philosophy, cultural, ethno-, socio- and psycholinguistics, linguistics, communicative, cognitive- and functional linguistics, so as text linguistics, determine the educational-pedagogical discourse, the main purpose of which is to construct in the process of learning a special cognitivecommunicative space that makes it possible to form the linguistic personality of the student. Most scientists consider the native language learning model prospective to solve the educational problem based on a combination of approaches such as skills approach, functional-stylistic approach, communicative-activity approach, person-centred approach, as well as text-centric one, which enables the implementation of all these approaches on a textual basis. However, the development of the priority branches of linguistics, as well as the communicative and cognitive methods, influenced the formation of new approaches to the teaching of the native language from the point of view of Ukrainian studies, ethnopedagogy and cultural studies, since the communicative strategies of the speaker are adjusted by the connection of the language with the culture of the people.

Key words: communicative strategy, communicative tactics, intention, communicative method, cognitive method, concept, communicative-pragmatic skills.

Постановка проблеми. Когнітивно-дискурсна наукова парадигма, зорієнтована на вивчення мови не лише як семіотичної системи, а й як знаряддя комунікації та впливу, визначає вектори розвитку сучасного мовознавства та лінгводидактики, об'єктом вивчення яких стає процес набуття і переробки інформації, що безпосередньо пов'язаний з реалізацією когнітивної діяльності людини. Дослідження взаємозв'язку мови як когнітивного процесу та сприйняття людиною предметного світу демонструє, яким чином у людському мисленні відображається «різноманіття просторових конфігурацій, а також які з них є найбільш релевантними для людини та отримують своє мовне вираження» [11, с. 94]. Це, без сумніву, зумовлює зміщення акцентів у процесі навчання мови.

Тенденції комплексного підходу до вивчення мовних явищ на грунті психології, соціології, філософії, культурології, етно-, соціо- та психолінгвістики, лінгвокультурології, комунікативної, когнітивної, функційної лінгвістики, лінгвістики тексту, нових розгалужень усередині мовознавчих дисциплін детермінують навчально-педагогічний дискурс, головне призначення якого - вибудувати в процесі навчання особливий когнітивно-комунікативний простір.

Мета статті - виявити вплив основних тенденцій розвитку мовознавчої науки на зміст шкільної мовної освіти; окреслити перспективи реалізації комунікативно-прагматичної основи навчання української мови.

Виклад основного матеріалу. Основним завданням шкільного курсу рідної мови залишається формування мовної особистості учня. Огляд фахової періодики засвідчив, що більшість науковців особливо перспективною для розв'язання означеного освітнього завдання вважає модель навчання рідної мови, що грунтується на поєднанні таких підходів, 
як компетентнісний, згідно з яким освітній процес має бути спрямований на формування й розвиток ключових і предметних компетентностей особистості, що визначають іiі здатність до соціальної адаптації в суспільстві; функційно-стилістичний, який «дає змогу усвідомити взаємозв'язок фонових знань iз функціональними аспектами мови та мовлення, з'ясувати закономірності використання стилістичних ресурсів мови в різноманітних комунікативних актах, відпрацювати вміння доцільно використовувати мовні одиниці залежно від змісту висловлювання, мети, ситуації та сфери спілкування, враховувати їхню національно-культурну семантику, особливості іiі вияву в соціально-мовленнєвих ситуаціях [1, с. 297]; комунікативно-діяльнісний, що сприяє вихованню мовної особистості у процесі мовленнєвої діяльності та передбачає формування комунікативних умінь і навичок; особистісний, який полягає у визнанні особистості як продукту соціального розвитку, носія культури, інтелектуальної та моральної свободи й передбачає опору на природний процес саморозвитку й самореалізацію особистості, а також текстоцентричний, який уможливлює реалізацію всіх названих підходів на текстовій основі

Проте розвиток пріоритетних галузей лінгвістики вплинув на формування нових підходів до навчання рідної мови - українознавчого, етнопедагогічного, культурологічного, оскільки комунікативні стратегії мовця корегуються не лише загальною стратегією комунікативної ситуації, а й зв'язком мови з культурою народу, його побутом, звичаями, міфологією, менталітетом. Тому одним із напрямів державної освітньої політики є принцип iї органічного зв'язку з національною історією та культурою. Ось чому в процесі формування мовної особистості важливою є не лише мовна компетенція, а й її етнічні складники.

Визначені підходи до вивчення мови активізували комунікативну методику, завданням якої $є$ «формування комунікативно компетентної особистості, здатної вільно й легко висловлюватися з будь-яких питань, виявляючи високий рівень мовної культури, дбаючи про якості власного мовлення» [10, с. 6], та когнітивну - «сукупність взаємопов'язаних та взаємозумовлених способів і засобів опанування мовних одиниць як основи пізнання й формування концептуальної та мовної картини світу і певного результату створення образу світу в уяві кожного» $[10$, с. 5]. За такого підходу мовні одиниці вивчають як концепти глибинні значення розгорнутих змістових структур та особливі сигнали культурної інформації. Зауважимо, що українська дослідниця О. Копусь розглядає категорію концепту в межах лінгвокогнітивного та лінгвокультурологічного підходів, презентованих у працях О. Кубрякової, О. Селіванової, В. Жайворонка та ін. Уважаючи текстову компетенцію найвищим щаблем філологічного осягнення текстового концепту, О. Копусь докладно вивчила методику концептуального аналізу художнього твору [7, с. 55].

Тексти різних типів і стилів мовлення, представлені у шкільних підручниках, уможливлюють удосконалення мовних, мовленнєвих, культуромовних, естетичних, творчих умінь і навичок учнів, сприяють засвоєнню стилістичних норм. Проте врахування лише змістового боку висловлення не завжди гарантує ситуацію успіху, у зв'язку з чим останнім часом 3'явився науковий інтерес до змісту і структури дискурсної компетенції - «здатності мовної особистості будувати і сприймати цілісні дискурси різних типів (усні й писемні) відповідно до комунікативного наміру в межах конкретної ситуації спілкування з урахуванням специфіки їх семантико-прагматичної та граматичної організації на макро- і мікрорівні та взаємозв'язку екстралінгвістичних і лінгвістичних компонентів» [8, с. 256].

Як бачимо, комунікативна та когнітивна методики доповнюють одна одну і «забезпечують досягнення основної мети мовної освіти - формування й розвиток комунікативної компетенції кожного, хто вивчає українську мову як державну і як рідну» [3, с. 15].

Комунікативна діяльність суб'єктів навчання неодноразово була предметом наукового аналізу українських та закордонних учених (М. Барболін, О. Бодалєв, М. Вашуленко, Ф. Гоноболін, І. Зимня, I. Зязюн, Г. Китайгородська, М. Каган, В. Кан-Калик, О. Леонтьєв, М. Лісіна, С. Рубінштейн, В. Сухомлинський, Г. Хорошавіна, І. Дроздова, О. Горошкіна, Н. Голуб, С. Омельчук та ін.). У працях згаданих дослідників представлені різні аспекти комунікативної діяльності, проте вчені переконані, що ефективне іiі формування слід пов'язати передусім з упровадженням принципу комунікативної спрямованості навчання, який передбачає побудову навчального процесу за моделлю реальної комунікації.

Щорічні підсумки ЗНО та багаторічний досвід роботи з першокурсниками, на жаль, засвідчують низький рівень сформованості комунікативної діяльність значної частини учнів. Цілком очевидно, що знання мовної теорії, яку переважно презентують учителі, не гарантує школярам успіхів у процесі комунікативної діяльності. Більше того, традиційні підходи до навчання мови в школі не дають можливості вийти за вузькі рамки аналізу закодованої винятково мовними засобами інформації, яким властивий такий феномен, як семантика. До семантики в широкому смислі, на думку О. Кибрика, належить «уся інформація, яку має на увазі мовець під час мовлення і яку потрібно відновити адресатові повідомлення для правильної інтерпретації висловлювання» [4, с. 25]. I. Кобозєва зі свого боку слушно зауважує, що сучасна епоха розвитку лінгвістики - це «епоха семантики, центральний статус якої в колі лінгвістичних дисциплін безпосередньо зумовлений тим, що основна функція людської мови - це засіб спілкування, засіб кодування і декодування певної інформації, яка переходить від однієї людини до іншої не безпосередньо, а за допомогою матеріальних сутностей - мовних виразів» [6, с. 25]. Аналіз змісту шкільних підручників засвідчив, що в них практично не представлена інформація про те, як вибудовувати комунікативну стратегію відповідно до комунікативного наміру та умов спілкування, а також як контролювати його хід. Так, шкільні підручники не містять інформації про таку процесуальну величину комунікативної ситуації, як комунікативна взаємодія (інтерактивність), що є об'єктом вивчення комунікативної лінгвістики. $€$ й інше пояснення такій прикрій ситуації: більшість учителів не ставить спеціального завдання щодо оволодіння учнями механізмами комунікативної діяльності.

Переконані, що процес формування мовної особистості буде успішним, якщо розглядати мовленнєву діяльність у контексті загальнопсихологічної теорії діяльності (О. Леонтьєв), найважливішими складниками якої психолінгвістика вважає мотив (причина, поштовх до початку діяльності), мету (усвідомлене уявлення про результат, якого необхідно досягти в процесі діяльності), дію (здійснення чого-небудь із конкретною метою), операцію (спосіб здійснення дій) [2, с. 60]. 
Отже, важливим аспектом означеної проблеми є активізація мотиваційного ресурсу школярів, адже саме мотив формує комунікативний намір (інтенцію), готовність мовця до здійснення мовленнєвих дій. Комунікативний намір визначає роль мовця як учасника спілкування та конкретну мету його висловлювання. Це означає, що такий структурний компонент уроку, як мотивація навчальної діяльності, не може бути формальним - це по-перше.

По-друге, для мовця важливо не просто відчувати себе учасником акту спілкування, а досягати певної прагматичної мети, обирати ефективні комунікативні стратегії і тактики відповідно до умов спілкування. Урахування суб'єктивного чинника мовленнєвої дії стало предметом дослідження багатьох учених (Н. Арутюнова, Ф. Бацевич, В. Карабан та ін.), у мовознавчій науці це вплинуло на розвиток нової галузі - лінгвістичної прагматики (або прагматичної лінгвістики). Очевидно, тому методисти наполягають на виокремленні прагматичного компонента у навчанні мови (див. напр. [3]).

По-третє, комунікативні стратегії визначають такі актуальні сьогодні аспекти комунікації, як екологічність та етичність (див. напр. [5; 9; 12]), що продукують позитивні емоції адресата і сприяють гармонійній взаємодії комунікантів.

Висновки. Отже, засвоюючи теорію, учні не формують уміння оцінювати ситуацію спілкування і враховувати особистість адресата, послуговуватися комплексом стратегій і тактик відповідно до інтенції 3 метою досягнення успіху, з'ясовувати комунікативні прагматичні смисли у контексті та використовувати прагматично орієнтовані мовні одиниці й мовленнєві засоби прагматичної діяльності. Сучасний етап розвитку лінгвістики та суміжних 3 нею наукових галузей диктує необхідність комунікативно-прагматичної переорієнтації методики навчання мови в закладі загальної середньої освіти, що зумовлює необхідність внесення коректив до змістового наповнення підручників з української мови, зоріснтованих переважно на лінгвоцентричну репрезентацію мовних явищ, що не дає можливості сформувати в учнів комунікативно-прагматичні вміння й навички.

Перспективи подальших наукових пошуків у контексті окресленої проблеми пов'язуємо з укладанням системи комунікативно-прагматичних вправ.

\section{СПИСОК ВИКОРИСТАНОЇ ЛІТЕРАТУРИ}

1. Бадер В. І. Функціонально-стилістичний підхід у формуванні культури мовлення студентів-філологів / В. І. Бадер // Лінгвістичні студії: зб. наук. пр. Донецьк. нац. ун-ту. - Донецьк : ДонНУ, 2009. Вип. 19. - С. 297-301.
2. Воробйова Л. М. Основи психолінгвістики: підручник / Л. М. Воробйова. - Рівне : Видавець Зень О., 2007. - 192 с.

3. Дружененко Р. Перспективи актуалізації комунікативно-прагматичної основи навчання української мови / Р. Дружененко // Українська мова і література в школах України. - 2014. - № 1 (130). - С. 15-18.

4. Кибрик А. Е. Очерки по общим и прикладным вопросам языкознания / А. Е. Кибрик. - М. : Изд-во МГУ, 1992. - 336 с

5. Киселюк Н. П. Екологічні та емоційні аспекти етичних норм комунікації в англомовному дискурсі / Н. П. Киселюк // Наукові записки Національного університету «Острозька академія» : наук. журнал. Острог : Вид-во Нац. ун-ту «Острозька академія». 2019. - Вип. 5 (73). - С. 32-34. - (Серія «Філологія»).

6. Кобозева И. М. Лингвистическая семантика: учеб. пособ. / И. М. Кобозева. - М. : Эдиториал УРCC, 2000. - $352 \mathrm{c}$.

7. Копусь О. Технологія навчання майбутніх магістрів-філологів з опертям на концептуальний аналіз художнього тексту / О. Копусь // Теоретична і дидактична філологія: зб. наук. пр. Переяслав-Хмельницьк. держ. педагогіч. ун-ту ім. Григорія Сковороди. Переяслав-Хмельницький, ФОП Лукашевич О. М., 2012. - Вип. 12. - С. 51-56.

8. Кучерява О. Система роботи з формування дискурсивної компетенції у сфері писемної комунікації / О. Кучерява // Вісник Львівського університету. 2010. - Вип. 50. - С. 254-261. - (Серія «Філологія»).

9. Панченко Н. Н. Правда и искренность в экологичной/неэкологичной коммуникации / Н. Н. Панченко // Научный диалог. - 2012. - № 12. - С. 124-135. (Серия «Филология»).

10. Пентилюк М. Концепція когнітивної методики української мови / М. Пентилюк, О. Горошкіна, А. Нікітіна // Дивослово. - 2004. - № 8. - С. 5-9.

11. Сошко О. Г. Метафоричне переосмислення просторових ознак у фразеологізмах на позначення внутрішніх характеристик людини (на матеріалі української, німецької та англійської мов / О. Г. Сошко // Наукові записки Національного університету «Острозька академія» : наук. журнал. - Острог : Видво Нац. ун-ту «Острозька академія». - 2019. - Вип. 5 (73). - С. 93-95. - (Серія «Філологія»).

12. Шаховский В. И. Экологичность стилистики публичного общения [Электронный ресурс] / В. И. Шаховский, Н. Г. Солодовникова // «Медиаскоп» : электронный научный журнал. - 2012. - Вып. 2. URL: http://www.mediascope.ru (дата звернення: 20.05. 2019).

Дата надходження до редакиї: 21.06.2019 p. 